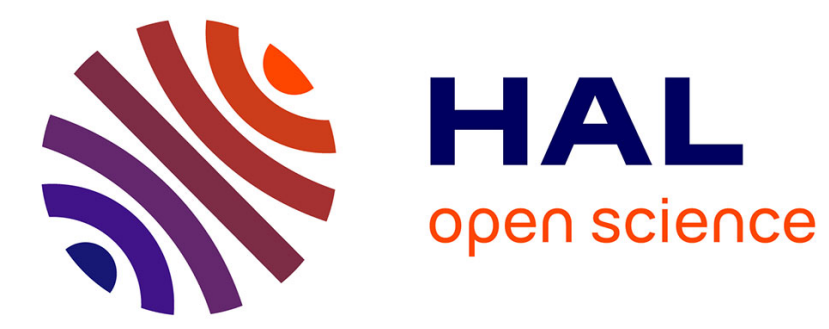

\title{
Book Review: Martin Priwitzer (2007) Ernst Kretschmer und das Wahnproblem (Stuttgart: Franz Steiner). Pp. xiv + 314. 49.00. ISBN 978-3-515-08562-5
}

Eric J. Engstrom

\section{- To cite this version:}

Eric J. Engstrom. Book Review: Martin Priwitzer (2007) Ernst Kretschmer und das Wahnproblem (Stuttgart: Franz Steiner). Pp. xiv + 314. 49.00. ISBN 978-3-515-08562-5. History of Psychiatry, 2008, 19 (2), pp.239-241. 10.1177/0957154X080190020902 . hal-00570922

\section{HAL Id: hal-00570922 \\ https://hal.science/hal-00570922}

Submitted on 1 Mar 2011

HAL is a multi-disciplinary open access archive for the deposit and dissemination of scientific research documents, whether they are published or not. The documents may come from teaching and research institutions in France or abroad, or from public or private research centers.
L'archive ouverte pluridisciplinaire HAL, est destinée au dépôt et à la diffusion de documents scientifiques de niveau recherche, publiés ou non, émanant des établissements d'enseignement et de recherche français ou étrangers, des laboratoires publics ou privés. 
his life's work on making the case for the intelligibility of schizophrenia in psychological and social terms. Arguably, such a difference amounts to a fundamental point rather than a minor detail for authors working in the history of ideas. As regards the discussion of Fairbairn, the problems and limitations of taking a history-of-ideas approach become more apparent. Miller presents Fairbairn to some degree as an isolated figure largely ignored by a monolithic London psychoanalytic establishment. The fact that Fairbairn's professional career was based in Edinburgh does not mean that he was marginalized - far from it. Indeed, Fairbairn was actively involved in the British Psychoanalytical Society, a body characterized by factionalism and theoretical-clinical controversies from the early 1940s onwards. Within this society a split emerged between those from the Freudian tradition, aligned with Anna Freud, and followers of Melanie Klein, whose theory of the paranoid-schizoid and depressive positions in the first year of life challenged Freudian orthodoxy. Although Fairbairn's emphasis on the development of the ego went on to reject Freud's instinctual model of human motivation based on the id, he was in large part influenced by Klein as a transitional figure in the emergence of a fully realized object relations theory of personality and psychopathology. To consider Fairbairn as a leading light of the Scottish personalist tradition is a fair representation of his philosophical outlook, but one that is also partial in terms of his clinical theory and practice.

For clinicians with an interest in the philosophical framework of practice and its implications, there is much to be found in Miller's analysis of the Scottish personalist tradition. Likewise, the book will be of special interest to those working in the field of Scottish cultural history and philosophy. As an introduction to Laing, anti-psychiatry and critical psychiatry, the book provides a reliable and informed guide to the concepts and issues that continue to drive the debate on the dominance of the biological model in the treatment of mental disorder.

IAN CARTHY University of Glasgow

Martin Priwitzer (2007) Ernst Kretschmer und das Wahnproblem (Stuttgart: Franz Steiner). Pp. xiv + 314. €49.00. ISBN 978-3-515-08562-5.

To the extent that he is remembered at all, Ernst Kretschmer is certainly best known for his monograph Körperbau und Charakter (1921) and his attempt to map athletic, asthenic and pyknic body types onto their respective personality traits and psychopathologies. By the time Kretschmer died in 1964, his book had gone through more than twenty editions and had shaped the attitudes of an entire generation of German psychiatrists. It is surprising, therefore, that instead of focusing upon this book, Martin Priwitzer has 
chosen to analyse the development of Kretschmer's work on delusion and paranoia prior to the publication of Körperbau und Charakter, that is, between 1914 and 1921. These were the years of Kretschmer's training as a psychiatrist, his military service during World War I, and his subsequent work with Robert Gaupp at the psychiatric clinic in Tübingen. Priwitzer's book is not so much an account of Kretschmer's life and career as an extended analysis of his early publications.

In these early works, Priwitzer locates many of the concepts that would later be integrated into Kretschmer's constitutional nosology. He stresses Kretschmer's early efforts to delineate the role of character traits and reaction types using 'multi-dimensional diagnostic techniques'. Priwitzer patiently and clearly lays out the basic tenets of Kretschmer's evolving thought, stressing that his ultimate aim was to develop a more flexible approach towards mental phenomena that would do justice to both its biological and psychological dimensions. Driving this point home to contemporary readers, Priwitzer recounts an extensive, late twentieth-century case history to demonstrate that Kretschmer's multidimensional diagnostic technique has lost none of its relevance for contemporary psychopathology. Although in his own day, Kretschmer was criticized for being too psychological, at least initially he saw himself working within a Kraepelinian framework, especially in the sense of striving to extend and deepen clinical understanding of manicdepressive disorders. More so than many of his contemporaries, however, Kretschmer was aware that clear and sharp nosologies were purchased at the high price of impoverishing clinical symptomatology and aetiological understanding.

Not surprisingly, the articulation of such views brought Kretschmer into conflict with advocates of the Kraepelinian school in Munich. Priwitzer devotes considerable attention to critiques of Kretschmer's work and his response to them. Although in general that work was favourably received by Robert Gaupp, Eugen Bleuler, Karl Jaspers and others, Kraepelin and especially his student, Eugen Kahn, were at first decidedly critical of it. Kahn questioned whether distinct character types could give rise to paranoia or serve as a basis for clinical classifications, while also casting doubt on the empirical basis of Kretschmer's case studies. Priwitzer thinks that this sharp reception of Kretschmer's ideas turned him away from multidimensional diagnosis and intuitive psychological understanding and eventually pushed him towards quantification and classification - this in spite of the fact that Kretschmer's concept of 'sensitive Beziehungswahn' would turn out to be the more promising and lasting of his achievements.

Unfortunately, the book's structure and narrative organization are strongly skewed by a rather narrow focus on specific sources, with entire sections devoted to one particular archival file or document. Instead of crafting his own story-line, Priwitzer has far too often simply allowed historical documents to drive his narrative. Furthermore, he engages in a peculiar 
method of historical analysis. After devoting large sections of the book to the specific case studies as published in Kretschmer's work, Priwitzer then dives into the archives in Tübingen to locate the hospital files on the patients that Kretschmer observed. He then assesses those hospital files and compares them with Kretschmer's published accounts. According to Priwitzer, the aim of this method is to examine Kretschmer's modus operandi - the practical work of transforming clinical observation into scientific premise - and to 'analyse potential weaknesses in his account' (p. 169). Priwitzer is only partially successful in this endeavour, because he fails adequately to contextualize his sources and lacks the analytic framework needed to interpret them.

The fact that Priwitzer concentrates so narrowly on Kretschmer's own case studies and the responses that his writings elicited among psychiatric colleagues constitutes both the greatest strength and weakness of the book. Priwitzer's close reading of the sources succeeds in giving us a good sense of some of the issues at stake in German psychiatry post-1914 and of the growing criticisms that were directed at the Munich school. At the same time, without itself aspiring to be a full-fledged biography, the book never escapes its own narrowly biographic perspective. Priwitzer describes this book as 'only a beginning' (p. 265) of a more comprehensive account of Kretschmer's work. In particular, he believes that further work is needed to explore how this early work influenced or underpinned Körperbau und Charakter and what role Kretschmer's concepts had on contemporary discussions of heredity, eugenics and racial hygiene. These are laudable aims and important questions for any twentieth-century history of psychiatry in Germany; but to answer them in future work, Priwitzer will have to liberate himself from the thrall of his archival sources and engage broader interpretations and narrative strategies.

ERIC J. ENGSTROM Humboldt University, Berlin 